\title{
MIMO信号検出の低演算量化と二偏波チャネル測定值を用い た特性評価
}

\author{
Low-Complexity MIMO Signal Detection and Evaluation of its Character- \\ istics using Dual-Polarized Channel Measurement
}

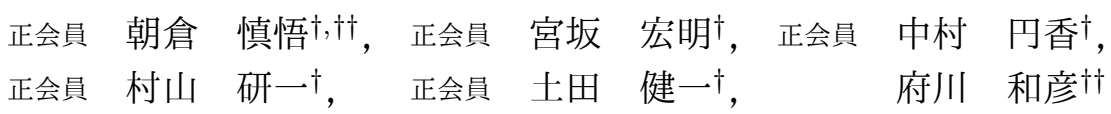

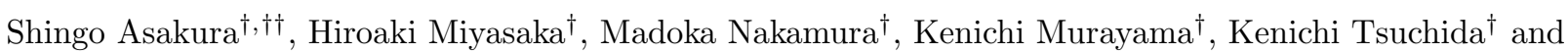
Kazuhiko Fukawa ${ }^{\dagger \dagger}$

\begin{abstract}
あらまし 日本放送協会 $(\mathrm{NHK})$ では, $8 \mathrm{~K}$ スーパーハイビジョン等の大容量コンテンツを配信するため, 次世代地上デジタル放送 の研究開発を進めている。これまでに，水平偏波と垂直偏波を同時に用いる偏波 MIMO 伝送や，優れた誤り訂正符号である LDPC 符号などの要素技術を検討してきた。地上デジタル放送は，衛星放送と異なり建造物による遮蔽や室内などの見通し外伝搬環境となり 得るが，次世代地上放送では現行と同等もしくはそれ以上の受信性能が求められる．そこで，実測の劣悪な伝搬環境を想定し，偏波 MIMO 伝送の信号検出アルゴリズムを検討する. 具体的には, LDPC 符号器へ入力するビット対数尤度比を求める際，チャネル行 列の $\mathrm{QR}$ 分解に基づき，信号候補数をチャネル行列の条件数に応じて削減する．この制御により，受信特性の劣化を抑えつつ信号検 出の演算量を効果的に削減できる，さらに演算量を削減するため, Complex SD (Sphere Decoding) の手法を導入し，加えて受信機 ではビット対数尤度比の数值範囲が限られるので, ビット対数尤度比のクリッピングを検討する. 劣悪な伝搬条件下で計算機シミュ レーションを行い，提案手法の有効性を明らかにする.
\end{abstract}

キーワード：次世代地上放送, $8 \mathrm{~K}$ スーパーハイビジョン, MIMO 信号検出，低演算量，偏波 MIMO 伝送，LDPC 符号

\section{1. ま え がき}

NHK では, 次世代の高臨場感映像・音響システムとして 8K スーパーハイビジョン（SHV; Super Hi-Vision）の研 究開発を進めている. 2018 年 12 月より, 衛星放送による $4 \mathrm{~K} \cdot 8 \mathrm{~K}$ の本放送が開始された。一方, 次世代の地上放送に おいても, 固定受信で $8 \mathrm{~K} \mathrm{SHV}$, 移動受信でハイビジョンの 大容量コンテンツを伝送可能にする技術の検討が行われて いる. NHK 放送技術研究所では，己れまでに水平 $(\mathrm{H} ; \mathrm{Hor}-$ izontal) 偏波, 垂直 (V; Vertical) 偏波を同時に用いて複数 のビットストリームを多重化する偏波 MIMO(Multi-Input Multi-Output) 技術, シャノン限界に迫る優れた誤り訂正 符号である LDPC(Low-Density Parity-Check) 符号など の要素技術を検討すると共に, これらの機能を変復調試作装 置に実装して室内・野外実験を行っている ${ }^{1)}$. 2016 年 8 月 には, ブラジル・リオデジャネイロで開催された夏季オリン ピックに合わせ, 上記の変復調試作装置を用いた $8 \mathrm{~K}$ 地上伝

2019 年 1 月 29 日受付, 2019 年 6 月 10 日再受付, 2019 年 7 月 19 日採録 †日本放送協会

（干 157-8501 東京都世田谷区砧 1-10-11，TEL 03-5494-3454） ††東京工業大学

（₹ 152-8550 東京都目黒区大岡山 2-12-1，TEL 03-5734-3126）
送デモが現地で実施された．筆者らは現地放送局と協力し， 送信設備を活用してリオデジャネイロ市内で偏波 MIMOOFDM(Othogonal Frequency Division Multiplexing) 伝 送の野外実験を実施した。 ${ }^{2)}$

我が国における地上デジタル放送（ISDB-T; Integrated Services Digital Broadcasting - Terrestrial) ${ }^{3)}$ は, 衛星放 送と異なり固定受信においてもビルなどの建造物の影や室 内などの見通し外伝搬環境での受信も想定されており，次 世代地上放送でも同等もしくはそれ以上の受信性能が求め られる。しかしながら， $\mathrm{H}$ 偏波， $\mathrm{V}$ 偏波の反射特性の違い 等に起因して，見通し外伝搬環境における偏波 MIMO 波 は複雑なチャネル応答を持ち，一般的に劣悪な受信特性と なる。したがって, 次世代地上放送として偏波 MIMO 伝 送を想定し，上述の劣悪な受信環境における伝送特性を把 握すると共に，より効率的な受信方法を検討する必要があ る. ${ }^{4)}$

本稿では, 上記の劣悪な伝搬環境を想定し, 偏波 MIMO 伝 送の信号検出アルゴリズムを提案する．具体的には, LDPC 符号器へ入力するビット対数尤度比を求める際, チャネル 行列の $\mathrm{QR}$ 分解に基づき，信号候補数をチャネル行列の条 件数に応じて削減する. 条件数が高いサブキャリアは受信 
特性が劣化するため, 信号候補数を大きく設定する。一方, 条件数が低いサブキャリアは信号候補数を小さく設定する. サブキャリア毎に信号候補数を設定することで, 受信特性 の劣化を抑えつつ信号検出の演算量を効果的に削減できる.

MIMO 伝送における従来の信号検出アルゴリズムとして は，推定したチャネル行列を元に線形受信を行う ZF (Zero Forcing)や MMSE(Minimum Mean Square Error), 送 信信号の候補点を全探索する MLD(Maximum Likelihood Detection), MLD を階層型推定問題に変換し, 信号候補数 を削減する QRM(QR decomposition and M-algorithm)MLD などが知られている5). QRM-MLD は, MLDに比べ 若干の特性劣化を許容して計算量を低減できるものの, 生き 残り信号候補数はチャネル行列と関係なく設定されるので, 本稿の提案手法とは異なる. MIMO 伝送における計算量削 減アルゴリズムの先行研究例としては, $4 \times 4 \mathrm{MIMO}$ システ ムにおける QRM-MLD に対し，生き残り信号候補を適応 的に選択する手法が提案されている ${ }^{6}$. 従来の QRM-MLD では各ステージにおける全ての信号候補点と受信信号の二 乗誤差を算出するのに対し, この手法は象限抽出に基づく 信号候補点のランキングを生成し，その上位のみ受信信号 との二乗誤差を算出する. 計算量削減の指標が信号候補点 のランキングであることや, 誤り訂正符号にターボ符号を 用いている点などで本提案とは異なる. サブキャリアによ らず信号候補数を一定としているが, 実際の MIMO チャネ ルではサブキャリアによってチャネル状態が大きく変動す る場合があるため, 特性劣化を抑えるには信号候補数を十 分大きく設定する必要がある.これに対して本稿の提案手 法は, 必要な信号候補数をサブキャリア毎に設定するため, 特性劣化を抑えつつ効率的な演算量削減が可能である.ま た, サブキャリア毎に条件数を算出し, 閾值判定により信 号検出を切り替える手法が提案されている7). 具体的には, MLD と MMSE の切り替えであり, QRM-MLD の生き残 り信号候補数を細かく制御するという本稿での提案手法と は異なっている．帯域全体で条件数が高い伝搬環境の場合 には, 演算量削減の効果が限られる。一方, 本提案ではこの 様な伝搬環境でも演算量を効果的に削減することができる. また, MIMO チャネルの状況に応じて信号検出に関するパ ラメータを調整する手法としては, QRM-MLD の信号候補 数を最適化する手法 ${ }^{8)}$ や LLR(対数尤度比;Log Likelihood Ratio) のクリップ值を可変とする手法9) が提案されている. QRM-MLD の信号候補数を最適化する手法は, 受信信号 とそのレプリカとの二乗誤差が，しきい值以下になる信号 点候補を生き残り候補とする。このしきい值は, 前ステー ジの二乗誤差の最小值に, 隣接サブキャリア間の推定周波 数応答の差分から求めた值を加算したものに設定する. 次 世代地上放送の様にサブキャリア間隔が非常に狭いシステ ムでは, MIMO チャネルのサブキャリア間の差分（絶対值 二乗）がチャネル成分の絶対值二乗に比べ $10^{-6}$ 以下と極 めて小さい值となり, 受信機での固定少数点化が困難とな
る.これに反して, 本稿で用いる Complex SD は上記のし きい值を適切に設定することができ，また第一ステージと 第二ステージの信号検出で効率的な信号点探索が可能とな る. LLR のクリップ值を可変とする手法は, 信号対雑音電 力比に基づくビット誤り率によって一意に定めるものであ る. 信号検出後, LLR を入力值として MaxlogMAP 復号 に基づく軟判定復号で検討されているが, 本稿ではLLRを 初期值として LDPC 復号を行う軟判定を前提としている. LLR は受信機内での数值範囲が限られているためクリップ 值を一定とした．当然, LDPC 復号によって硬判定でも利 得を得ることができる.

一方, 地上放送を想定した偏波 MIMO 伝送の先行研究と しては, DVB-T ${ }^{10)}$ を両偏波を用いるシステムに拡張し，小 規模な野外実験が行われている11)。またフィンランド・へ ルシンキにて実施された偏波 MIMO の野外実験結果に基 づき, 屋外, 屋内で想定される移動受信に合わせて電波伝搬 モデルを構築する試みが行われている ${ }^{12)}$. 放送を想定した 偏波 MIMO 伝送の数少ない野外実験であるが，MIMO 信 号検出は検討されておらず，本稿とは異なる．また，米国 の地上放送方式である ATSC3.0 ${ }^{13)}$ は SISO(Single-Input Single-Output) だけでなく MIMO についても規定されて おり, 送受信システムの検討や SP（Scattered Pilot）の伝 送特性などが報告されている ${ }^{14) 15)}$ 。これらはいずれも伝搬 モデルを用いた，放送方式としての MIMO 伝送の特性検証 であり，本稿のように実際に野外で取得した MIMO チャ ネル，特に劣悪な伝搬環境を想定した信号検出を検討して いない.

本論文の構成は, まず 2 章で, 想定する受信機の構成に ついて説明する． 3 章では, 偏波 MIMO 伝送の信号モデル について述べる. 4 章では, MIMO 信号検出アルゴリズム に基づく従来の LLR の算出法を説明する．5 章では，提案 手法に基づく LLR の算出法を説明する． 6 章では, 野外実 験2) で取得したチャネル応答を用いた伝送シミュレーショ ンを実施し, 提案手法の有効性を明らかにする. 7 章では, 本稿のまとめと今後の課題について述べる.

\section{2. 受信機 の構成}

想定する受信機の構成を図 1 に示す．まず, 偏波共用アン テナで受信した $\mathrm{H}$ 偏波, $\mathrm{V}$ 偏波のベースバンド信号は, それ ぞれ A/D 変換された後, ガードインターバル (GI; Guard Interval)を除いて FFT (Fast Fourier Transform) 区間の 受信信号を切り出す. 次にキャリア周波数オフセットを検 出して周波数同期を行い, FFTにより時間領域の信号から 周波数領域の信号へ変換する. 続いて $\mathrm{SP}, \mathrm{CP}($ Continual Pilot) を検出し, 時間軸方向と周波数方向にチャネル周波数 応答を補間して推定する. 推定したチャネル周波数応答を用 いて MIMO の信号検出を行った後, SP, CP, AC(Auxually Channel) 信号, 制御信号 (TMCC; Transmission Management Configuration Control）を除いたデータのサブキャ 


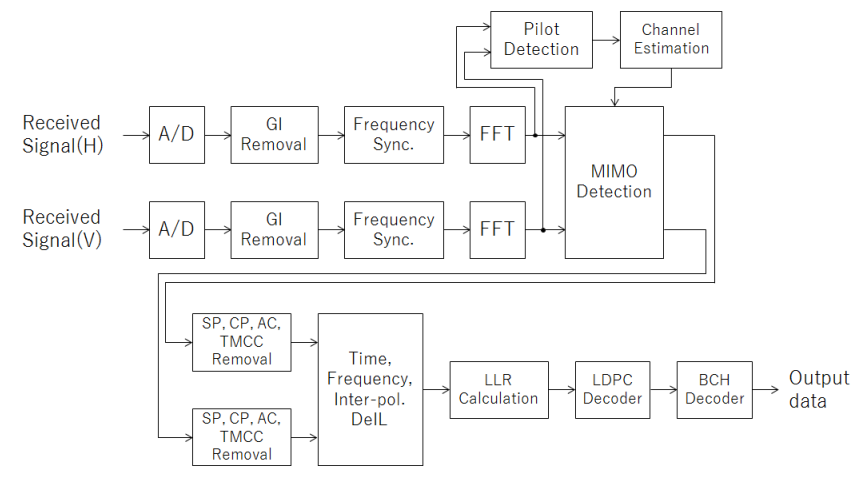

図 1 受信機のブロック図

リアに対して，時間・周波数・偏波間デインターリーブ(6) （DeIL; Deinterleave）を行い，各ビットに対応する LLR を算出する.この LLR を LDPC 復号器に入力し, その復 号結果を BCH（Bose Chaudhuri Hocquenghem）復号器 に入力した後, 出力データを得る.

\section{3. 偏波 MIMO 伝送の信号モデル}

次に偏波 MIMO の信号モデルについて説明する．なお 以降では, 信号は全て等価低域系とし複素包絡線で表す. まず，送信アンテナ素子数 $N_{t}$, 受信アンテナ素子数 $N_{r}$ は いずれも 2 とする. $l(l=0,1)$ 番目の受信アンテナにおけ る OFDM 信号のうち，あるサブキャリアにおける送信信 号, 受信信号を $x_{l}(i), y_{l}(i)$ と表す.ただし, $i$ は OFDM の シンボルを示す整数である. なお, 以降では OFDM シン ボル内のチャネルの時間変化は無視できると仮定し,$i$ の表 記を省略する. 偏波 MIMO の送信信号を $\mathrm{x}=\left[x_{0}, x_{1}\right]^{\mathrm{T}}$, 受信信号を $\mathbf{y}=\left[y_{0}, y_{1}\right]^{\mathrm{T}}$, チャネルの周波数応答を要素と するチャネル行列を $\mathbf{H}$, 雑音を $\mathbf{n}=\left[n_{0}, n_{1}\right]^{\mathrm{T}}$ とすると

$$
\begin{aligned}
\mathbf{y} & =\mathbf{H} \mathbf{x}+\mathbf{n} \\
& =\left[\begin{array}{ll}
h_{00} & h_{01} \\
h_{10} & h_{11}
\end{array}\right] \mathbf{x}+\mathbf{n}
\end{aligned}
$$

と表すことができる. なお, ${ }^{\mathrm{T}}$ は転置であり, $l=0,1$ はそ れぞれ， $\mathrm{H}$ 偏波， $\mathrm{V}$ 偏波の信号に対応する。簡単のため，信 号電力は 集合平均を $E[]$ として $E\left[\left|x_{l}\right|^{2}\right]=1$ とする.ま た, 各受信アンテナの受信増幅器は同一の特性を有すると仮 定するため, 雑音電力は $\mathrm{H}$ 偏波, $\mathrm{V}$ 偏波によらず一定とし, 平均雑音電力 $\sigma^{2}=E\left[\left|n_{l}\right|^{2}\right]$ と表す. 加えて, 雑音は互い に統計的独立なので, $\mathbf{n}$ の自己相関行列は $E\left[\mathbf{n n}^{\mathrm{H}}\right]=\sigma^{2} \mathbf{I}$ となる。 ただし, ${ }^{\mathrm{H}}$ は複素共役転置を表し, I は $2 \times 2$ の単 位行列である.

\section{4. 従来の LLR 算出法}

本稿では, MIMO 信号検出後に LDPC 符号の軟判定復 号を想定しており, LDPC 復号器への入力は各ビットの LLR である. 変調多值数 $2^{M}$ の変調信号における $q$ 番目 $(0 \leqq q \leqq M-1)$ のビットに着目して, 各種 MIMO 信号
検出に基づく従来の LLR の算出方法を述べる.

\section{4. $1 \mathrm{ZF}$}

式 (1) の両辺に Moore-Penrose 一般化逆行列 $\mathbf{H}^{+}=$ $\left(\mathbf{H}^{\mathrm{H}} \mathbf{H}\right)^{-1} \mathbf{H}^{\mathrm{H}}$ を乗算し

$$
\mathbf{H}^{+} \mathbf{y}=\mathbf{x}+\mathbf{H}^{+} \mathbf{n}
$$

を得る. 右辺第二項の雑音項が比較的小さいならば，左辺 を硬判定（量子化）すれば送信信号 $\mathrm{x}$ を検出できる．本稿 では, 左辺によって得られる ZF 復調後の受信信号点と平 均雑音電力を用いて，LLR を算出する，上記の雑音の自己 相関行列は, $E\left[\mathbf{n n}^{\mathrm{H}}\right]=\sigma^{2} \mathbf{I}$ であるから

$$
\begin{aligned}
E\left[\left(\mathbf{H}^{+} \mathbf{n}\right)\left(\mathbf{H}^{+} \mathbf{n}\right)^{\mathrm{H}}\right] & =E\left[\mathbf{H}^{+} \mathbf{n} \mathbf{n}^{\mathrm{H}} \mathbf{H}^{+\mathrm{H}}\right] \\
& =\mathbf{H}^{+} E\left[\mathbf{n} \mathbf{n}^{\mathrm{H}}\right] \mathbf{H}^{+\mathrm{H}} \\
& =\sigma^{2} \mathbf{H}^{+} \mathbf{H}^{+\mathrm{H}}
\end{aligned}
$$

と表される. $l$ 番目の受信アンテナにおいて, 式 $(2)$ の右辺 第二項の平均雑音電力 $\sigma_{l, z}^{2}$ は, 式 $(3)$ の $(l, l)$ 成分である. $\mathbf{H}^{+}$の $(u, v)$ 成分を $w_{u v}$ として

$$
\sigma_{l, z}^{2}= \begin{cases}\left(\left|w_{00}\right|^{2}+\left|w_{01}\right|^{2}\right) \sigma^{2} & (l=0) \\ \left(\left|w_{10}\right|^{2}+\left|w_{11}\right|^{2}\right) \sigma^{2} & (l=1)\end{cases}
$$

と表される. 次に, $\mathbf{H}^{+} \mathbf{y}=\left[\tilde{y}_{0}, \tilde{y}_{1}\right]^{\mathrm{T}}$ と定めると, $\tilde{y}_{l}$ は平均 值が送信信号の Gauss 分布となる. $l$ 番目アンテナにおけ る $2^{M}$ 個の送信信号点に対するインデックスを $k(0 \leqq k \leqq$ $\left.2^{M}-1\right)$ として送信信号点候補を $x_{k}, q$ ビット目が $b=0,1$ である送信信号インデックスの集合を $\tilde{S}_{b, l}^{q}, q$ ビット目の LLR $\lambda_{q, l}$ として

$$
\lambda_{q, l}=\ln \frac{\sum_{k \in \tilde{S}_{1, l}^{q}} \exp \left(-\left|\tilde{y}_{l}-x_{k}\right|^{2} / \sigma_{l, z}^{2}\right)}{\sum_{k \in \tilde{S}_{0, l}^{q}} \exp \left(-\left|\tilde{y}_{l}-x_{k}\right|^{2} / \sigma_{l, z}^{2}\right)}
$$

と表される．なお， $\mathbf{H}^{+} \mathbf{n}$ の要素である雑音成分間に相関が 生じるが，この相関は無視した．また，受信機内における LLR のダイナミックレンジは有限であるため, 閾值（LLR クリップ值）を $\lambda_{c}$ とする．以降の手法も同様とする.

\section{2 MMSE}

式 (1) の両辺に $\mathbf{W}=\mathbf{P} \mathbf{H}^{\mathrm{H}}$ を乗算し送信信号 $\mathbf{x}$ を推定 する．ただし， $\mathbf{P}=\left(\mathbf{H}^{\mathrm{H}} \mathbf{H}+\sigma^{2} \mathbf{I}\right)^{-1}$ と定める. 乗算結 果と送信信号の残差成分（雑音を含む）を $\mathbf{z}=\left[z_{0}, z_{1}\right]^{\mathrm{T}}$ と して

$$
\begin{aligned}
\mathbf{x}+\mathbf{z} & =\mathbf{W} \mathbf{y} \\
\Leftrightarrow \mathbf{z} & =(\mathbf{W H}-\mathbf{I}) \mathbf{x}+\mathbf{W} \mathbf{n} \\
& =-\sigma^{2} \mathbf{P} \mathbf{x}+\mathbf{P H}^{\mathrm{H}} \mathbf{n}
\end{aligned}
$$

と表される．また， $\mathbf{P}^{\mathrm{H}}=\mathbf{P}$ であり

$$
\begin{aligned}
E\left[\mathbf{z z}^{\mathrm{H}}\right] & =\sigma^{4} \mathbf{P} E\left[\mathbf{x x}^{\mathrm{H}}\right] \mathbf{P}+\mathbf{P} \mathbf{H}^{\mathrm{H}} E\left[\mathbf{n} \mathbf{n}^{\mathrm{H}}\right] \mathbf{H} \mathbf{P} \\
& =\sigma^{4} \mathbf{P}^{2}+\sigma^{2} \mathbf{P}\left(\mathbf{P}^{-1}-\sigma^{2} \mathbf{I}\right) \mathbf{P}
\end{aligned}
$$




$$
=\sigma^{2} \mathbf{P}
$$

となる.ただし, $E\left[\mathrm{xx}^{\mathrm{H}}\right]=\mathbf{I}$ を用いた. $l$ 番目の受信ア ンテナにおける, $\mathbf{W}$ 乗算後の誤差信号の平均電力 $\sigma_{l, m}^{2}$ は, 式 $(7)$ の $(l, l)$ 成分であるから

$$
\sigma_{l, m}^{2}=\sigma^{2} p_{l l}
$$

ただし $p_{l l}$ は行列 $\mathbf{P}$ の $(l, l)$ 成分である. $\mathbf{W} \mathbf{y}=\left[\hat{y}_{0}, \hat{y}_{1}\right]^{\mathrm{T}}$ と 定め, $\hat{y}_{l}$ は平均值が送信信号の Gauss 分布と仮定する. $l$ 番 目受信アンテナにおける $\hat{y}_{l}$ に基づく $q$ ビット目の $\operatorname{LLR} \lambda_{q, l}$ は, 式 (5) と同様に

$$
\lambda_{q, l}=\ln \frac{\sum_{k \in \tilde{S}_{1, l}^{q}} \exp \left(-\left|\hat{y}_{l}-x_{k}\right|^{2} / \sigma_{l, m}^{2}\right)}{\sum_{k \in \tilde{S}_{0, l}^{q}} \exp \left(-\left|\hat{y}_{l}-x_{k}\right|^{2} / \sigma_{l, m}^{2}\right)}
$$

と表される.なお, $\mathrm{z}$ の要素間の相関は無視した。

\subsection{MLD}

MLD は最適信号検出であるが，演算量が膨大になると いう問題がある．以下ではこれを説明する．まず，ZFや MMSE と異なり, MLD はノルム 2 乗 $\|\mathbf{y}-\mathbf{H} \hat{\mathbf{x}}\|^{2}$ が最小 となる送信信号の候補点 $\hat{\mathbf{x}}$ を全探索する. $\hat{\mathbf{x}}=\left[\hat{x}_{0}, \hat{x}_{1}\right]^{\mathrm{T}}$ を 同時に推定するため, サブキャリア変調方式の変調多值数を $2^{M}$ とした時, 送信信号の候補数は $2^{2 M}$ となり, 演算量が 膨大になる. LLR 算出は, 送信信号候補 $\mathrm{x}_{k^{\prime}}$ が与えられた ときの受信信号 $\mathbf{y}$ の確率密度関数を ZF,MMSE と同様に Gauss 分布で表す。送信信号は $2^{2 M}$ 通りの組み合わせがあ り, 送信信号候補のインデックスを $k^{\prime}\left(0 \leqq k^{\prime} \leqq 2^{2 M}-1\right)$ とおく. $l$ 番目アンテナ, $q$ ビット目が $b$ である送信信号 候補のインデックスの集合を $S_{b, l}^{q}$ とすると, $q$ ビット目の $\operatorname{LLR} \lambda_{q, l}$ は

$$
\lambda_{q, l}=\ln \frac{\sum_{k^{\prime} \in S_{1, l}^{q}} \exp \left(-\left\|\mathbf{y}-\mathbf{H x}_{k^{\prime}}\right\|^{2} / \sigma^{2}\right)}{\sum_{k^{\prime} \in S_{0, l}^{q}} \exp \left(-\left\|\mathbf{y}-\mathbf{H x}_{k^{\prime}}\right\|^{2} / \sigma^{2}\right)}
$$

と表される.

\subsection{QRM-MLD}

MLD では, $M$ が大きくなると送信信号の候補数が指数 関数的に増加するので, 演算量の削隇が課題となる. そこ で, チャネル行列 $\mathbf{H}$ を $\mathrm{QR}$ 分解し, 階層型推定問題に変換 する. $2 \times 2$ ユニタリ行列 $\mathbf{Q}$ と上三角行列 $\mathbf{R}$ を用いてチャ ネル行列を $\mathbf{H}=\mathbf{Q R}$ と表す．式 (1)より

$$
\begin{aligned}
\mathbf{y} & =\left[\begin{array}{ll}
h_{00} & h_{01} \\
h_{10} & h_{11}
\end{array}\right] \mathbf{x}+\mathbf{n} \\
& =\mathbf{Q}\left[\begin{array}{cc}
r_{00} & r_{01} \\
0 & r_{11}
\end{array}\right] \mathbf{x}+\mathbf{n}
\end{aligned}
$$

式 (11) の両辺に $\mathbf{Q}^{\mathrm{H}}$ を乗算し

$$
\mathbf{Q}^{\mathrm{H}} \mathbf{y}=\left[\begin{array}{cc}
r_{00} & r_{01} \\
0 & r_{11}
\end{array}\right] \mathbf{x}+\mathbf{Q}^{\mathrm{H}} \mathbf{n}
$$

を得る.ここで $\mathbf{y}^{\prime}=\mathbf{Q}^{\mathrm{H}} \mathbf{y}=\left[y_{0}^{\prime}, y_{1}^{\prime}\right]^{\mathrm{T}}, \mathbf{n}^{\prime}=\mathbf{Q}^{\mathrm{H}} \mathbf{n}$ とお

996 (178)
く. $\mathrm{QR}$ 分解の場合は $\mathrm{QQ}^{\mathrm{H}}=\mathrm{I}$ を満足するユニタリ行列 $\mathrm{Q}^{\mathrm{H}}$ を乗算するため雑音強調が発生せず, $\|\mathbf{n}\|^{2}=\left\|\mathbf{n}^{\prime}\right\|^{2}$ である. また, $r_{00}, r_{11}$ は正数に設定することが可能で, こ こでは正数になるよう $\mathbf{Q}$ を求める.ささらに， $r_{11} \geqq r_{00}$ と なるように送受信信号の入れ替えを行う。まず，第一段階 として式 (12)の第 2(1) 要素

$$
y_{1}^{\prime}=r_{11} x_{1}+n_{1}^{\prime}
$$

に着目し, 二乗誤差 $D_{1}=\left|y_{1}^{\prime}-r_{11} \hat{x}_{1}\right|^{2}$ が小さい順に上位 $s$ 番目までの候補点 $\hat{x}_{1}^{(t)}(0 \leqq t<s)$ を探索する. 次に第二 段階として探索した結果を式 (12)の第 1(0) 要素に代入し

$$
y_{0}^{\prime}=r_{00} x_{0}+r_{01} \hat{x}_{1}^{(t)}+n_{0}^{\prime}
$$

を得る、式 (13),(14) の二乗誤差の和

$$
\begin{aligned}
D & =\left|y_{1}^{\prime}-r_{11} \hat{x}_{1}\right|^{2}+\left|y_{0}^{\prime}-\left(r_{00} \hat{x}_{0}+r_{01} \hat{x}_{1}\right)\right|^{2} \\
& =D_{0}+D_{1}
\end{aligned}
$$

を計算するために取り得る送信信号の組み合わせは, $s 2^{M}$ 通りとなり，MLDに比べ受信性能の劣化を抑えつつ計算 量削減が可能である. LLR 算出は, 候補点削減後において $q$ ビット目が $b$ である送信信号候補のインデックスの集合 を $S_{b, l}^{\prime q}$ として, 式 (10) と同様に

$$
\lambda_{q, l}=\ln \frac{\sum_{k^{\prime} \in S_{1, l}^{\prime q}} \exp \left(-\left\|\mathbf{y}^{\prime}-\mathbf{R} \mathbf{x}_{k^{\prime}}\right\|^{2} / \sigma^{2}\right)}{\sum_{k^{\prime} \in S_{0, l}^{\prime q}} \exp \left(-\left\|\mathbf{y}^{\prime}-\mathbf{R} \mathbf{x}_{k^{\prime}}\right\|^{2} / \sigma^{2}\right)}
$$

と表される。

\section{5. 提案の LLR 算出法}

\subsection{MIMO 検出法}

4.4 で述べた従来の QRM-MLD は, チャネル応答が悪 条件（ブランチ間の相関が高く, $\mathbf{H}^{\mathrm{H}} \mathbf{H}$ の最小固有值が最 大固有值に比べて非常に小さい状態）の場合に, 生き残り パス数 $s$ を十分大きく設定することで, ZF や MMSE 等の 線形受信に比べて大幅に受信性能の劣化を抑えられる.し かしながら $s$ はサブキャリアによらず一定值に設定するた め, チャネル応答の条件が良いサブキャリアでは, 冗長な 計算を多く含むことになる，そこで, OFDM のサブキャリ ア毎にチャネルの状態 (条件数) に応じて $s$ を最適化する 手法を提案する. 提案の MIMO 検出法によって, 受信性能 の劣化を抑えつつ更なる計算量削減が期待できるＯOFDM のサブキャリアのインデックスを $n, n$ 番目のサブキャリ アにおける $\mathbf{H}$ を $\mathbf{H}_{n}$ と表し, $\mathbf{H}_{n}^{\mathrm{H}} \mathbf{H}_{n}$ の固有值を值の大き い順に $\zeta_{0, n}, \zeta_{1, n}\left(\zeta_{0, n} \geqq \zeta_{1, n}\right)$ とすると, 条件数 $\kappa_{n}$ は

$$
\kappa_{n}=\sqrt{\frac{\zeta_{0, n}}{\zeta_{1, n}}}
$$

と表される. 提案の MIMO 信号検出法では, $n$ 番目サブ キャリアの $s$ を $s_{n}$ とすると, $s_{n}$ を 


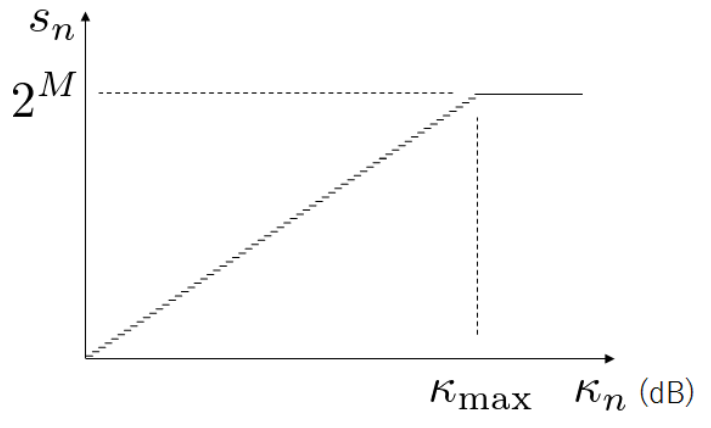

図 2 提案の MIMO 信号検出法における $s_{n}$ の設定

$$
s_{n}= \begin{cases}\left\lfloor 2^{M} \log \kappa_{n} / \log \kappa_{\max }\right\rfloor & \kappa_{n}<\kappa_{\max } \\ 2^{M} & \kappa_{n} \geqq \kappa_{\max }\end{cases}
$$

と制御する.ただし， $x\rfloor は x$ を越えない最大整数を表し， $\kappa_{\text {max }}$ は想定する条件数の最大值であり, 予め設定する. 条 件数を $\mathrm{dB}$ 表記とし, 式 (18) を図 2 に示す. 計算量削減 を目的とした提案であるが, 条件数を算出するための計算 が必要となる. 本稿では固定受信を扱い, チャネル応答に 時間変動のない準静的な伝搬環境を想定している. そのた め, OFDM シンボル毎ではなく, 十分長い時間間隔で条件 数を算出する.

\subsection{LLR 算出の演算量削減化}

QRM-MLD の式 (13) において, 二乗誤差が小さい順に 候補点 $\hat{x}_{1}$ を求めるためには, $2^{M}$ 個の候補点全てについて 二乗誤差を算出する必要がある. 式 (14) も同様である. こ の演算量を削減するために, LLRに実質的に寄与しない送 信信号候補は, 二乗誤差の計算から除外する. 具体的には, 受信信号 $\mathbf{y}^{\prime}$ を中心した半径 $C$ の円を描き, その内部の 候補点だけ二乗誤差を計算するアルゴリズム（SD;Sphere Decoding）を適用する.すなわち式 (15) より

$$
D_{0}+D_{1} \leqq C^{2}
$$

を満たす $\hat{\mathbf{x}}$ の二乗䛊差のみを計算する，本稿では，受信信 号, 送信信号候補点の実部と虚部を分けず, 複素数として 扱う手法（Complex SD）ㄱ) を用いる．まず極座標を導入 し, 複素数 $z$ の振幅 $R_{z}=|z|$, 位相 $\theta_{z}=\arg (z)$ とする. 式 (19) が成立するためには, 当然 $D_{1} \leqq C^{2}$ が成立しなけ ればならない. $D_{1}$ は余弦定理より

$$
\begin{aligned}
& D_{1}=R_{y_{1}^{\prime}}^{2}+r_{11}^{2} R_{\hat{x}_{1}}^{2}-2 R_{y_{1}^{\prime}} r_{11} R_{\hat{x}_{1}} \cos \left(\theta_{y_{1}^{\prime}}-\theta_{\hat{x}_{1}}\right) \leqq C^{2} \\
& \Leftrightarrow \cos \left(\theta_{y_{1}^{\prime}}-\theta_{\hat{x}_{1}}\right) \geqq \frac{1}{2 R_{y_{1}^{\prime}}{ }^{11} R_{\hat{x}_{1}}}\left(R_{y_{1}^{\prime}}^{2}+r_{11}^{2} R_{\hat{x}_{1}}^{2}-C^{2}\right)=\eta(20)
\end{aligned}
$$

である.ここで, $r_{11}$ は正数であることを用いた. $\eta>1$ の 場合, 半径 $C$ の円内に候補点は存在しない. $\eta<-1$ の場 合, 半径 $C$ の円内に振幅 $R_{\hat{x}_{1}}$ を持つ全ての送信信号候補 が含まれる. $-1 \leqq \eta \leqq 1$ の場合，式 $(20)$ より

$$
\begin{aligned}
& \left|\theta_{y_{1}^{\prime}}-\theta_{\hat{x}_{1}}\right| \leqq \cos ^{-1} \eta \\
& \Leftrightarrow \theta_{y_{1}^{\prime}}-\cos ^{-1} \eta \leqq \theta_{\hat{x}_{1}} \leqq \theta_{y_{1}^{\prime}}+\cos ^{-1} \eta
\end{aligned}
$$

を満たす $\hat{x}_{1}$ が候補点である。次に，探索した候補点 $\hat{x}_{1}^{(m)}(0 \leqq m<s)$ を用いて式 (15),(19)より

$$
D_{0}=\left|y_{0}^{\prime}-\left(r_{00} \hat{x}_{0}+r_{01} \hat{x}_{1}^{(m)}\right)\right|^{2} \leqq C^{2}-D_{1}
$$

を満たす $\hat{x}_{0}$ を式 $(20)$ と $(21)$ と同様に探索する.このよう にして, 受信信号を中心として半径 $C$ の円内に含まれる送 信信号の候補に対してのみ二乗誤差を算出することで，全 探索に比べ計算量を削減できる. 本手法は, 式 (20) と (21) を満たす候補点が $s$ 個となるよう半径 $C$ を設定する必要が ある. そこで, 以下の手順にしたがって半径 $C$ を設定する.

（1）式 (13)より, $x_{1}=\left(y_{1}^{\prime}-n_{1}^{\prime}\right) / r_{11} \simeq y_{1}^{\prime} / r_{11}$ の最 近傍点を選択する．送信信号のコンスタレーション は予め分かっているため, 単純な場合分けによって 選択可能である.

（2）選択した最近傍点に対し，自身以外の信号点が $s_{n}-1$ 個含まれるよう初期半径 $C_{s}^{\prime}$ を決定する.こ れも信号点配置が予めわかっているため, 各信号点 に対する $C_{s}^{\prime}$ はテーブルなどに記憶しておけばよく, その都度計算する必要はない.

(3) $C_{0}=r_{11} C_{s}^{\prime}$ を初期值とする. 最近傍点を選択し ていることにより, 半径 $C$ の円内に含まれる候補点 が $s_{n}$ 個に達しない場合は, $C_{s}^{\prime}$ を拡大し再度探索す る. 本稿ではこの更新を $C_{s}^{\prime} \leftarrow C_{s}^{\prime}+0.01$ とする. 受信信号 $\mathbf{y}^{\prime}$ と送信信号 $\mathbf{x}_{k^{\prime}}$ の二乗誤差 $\Delta_{k^{\prime}}=\| \mathbf{y}^{\prime}-$ $\mathbf{R x}_{k^{\prime}} \|^{2}$ として， $\Delta_{k^{\prime}}$ を值が小さい順に並べ，送信信号候 補の $q$ ビット目が $b=0,1$ である送信信号候補の内, $m$ 番 目の二乗誤差を $\Delta_{k^{\prime}, m}^{(b)}$ と表記する. 上位 $X$ 番目までを用 いると式 (16) は

$$
\lambda_{q, l} \simeq \ln \frac{\sum_{m=0}^{X-1} \exp \left(-\Delta_{k^{\prime}, m}^{(0)} / \sigma^{2}\right)}{\sum_{m=0}^{X-1} \exp \left(-\Delta_{k^{\prime}, m}^{(1)} / \sigma^{2}\right)}
$$

と近似される. 2 乗誤差が大きいものは実質寄与しないた め, LLR 算出に係る計算量を効率的に削減できる. $X=1$ とすれば最近傍点のみを候補点として用いる MaxLogMAP であり，全候補点を用いれば LogMAP と等価である.さ らに, LLR 算出は最近傍点における寄与が最も大きく, MaxLogMAP の場合, $\left|\lambda_{q, l}\right|=\left|\Delta_{k^{\prime}, 0}^{(0)}-\Delta_{k^{\prime}, 0}^{(1)}\right|$ と近似でき ることから

$$
\left|\Delta_{k^{\prime}, 0}^{(0)}-\Delta_{k^{\prime}, 0}^{(1)}\right|>\lambda_{c} \sigma^{2}
$$

を満たす場合は，式 (16) の計算自体を省略し

$$
\lambda_{q, l}=\operatorname{sgn}\left(\Delta_{k^{\prime}, 0}^{(0)}-\Delta_{k^{\prime}, 0}^{(1)}\right) \lambda_{c}
$$

とする.ただし, $\operatorname{sgn}($ ) は引数の符号を与える関数である. 式 $(24)$ を満足する場合, LLR をクリップ值 $\pm \lambda_{c}$ に置き換 える。 


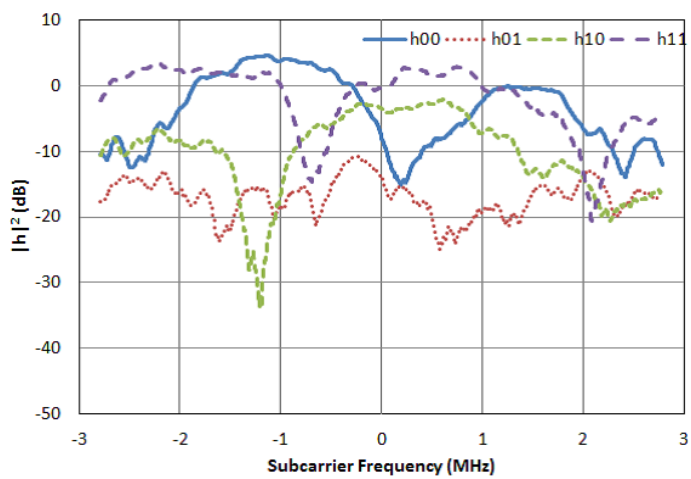

図 3 受信点 A の MIMO チャネル

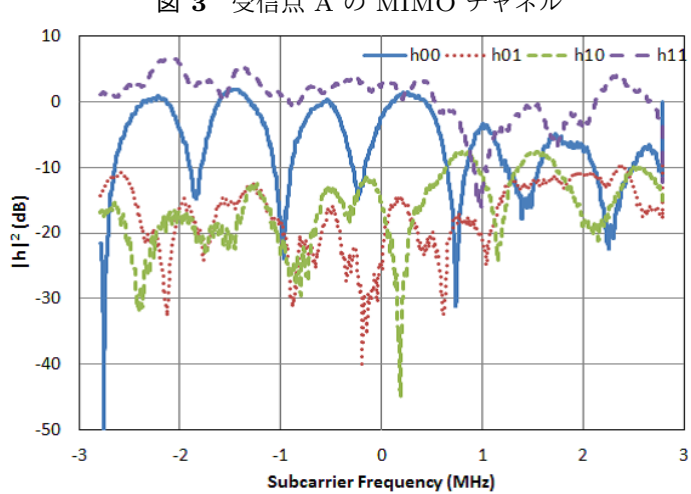

図 4 受信点 B の MIMO チャネル

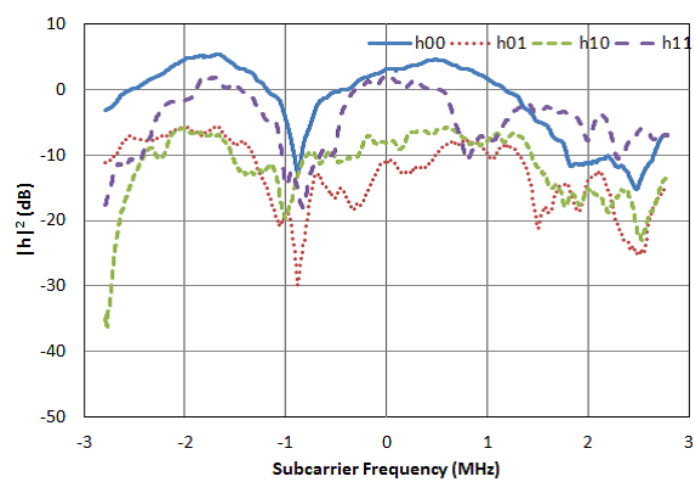

図 5 受信点 C の MIMO チャネル

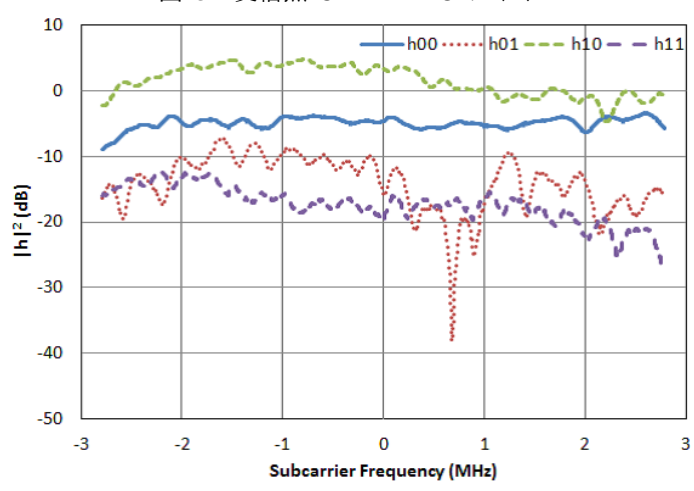

図 6 受信点 D の MIMO チャネル

\section{6. 伝送シミュレーション}

\subsection{MIMO チャネル}

本稿は固定受信を想定し, MIMO 伝送路は時間変動のな い静的なチャネルとする．チャネル行列は，ブラジル・リ オデジャネイロ市内で実施した野外実験のデータを用いる.

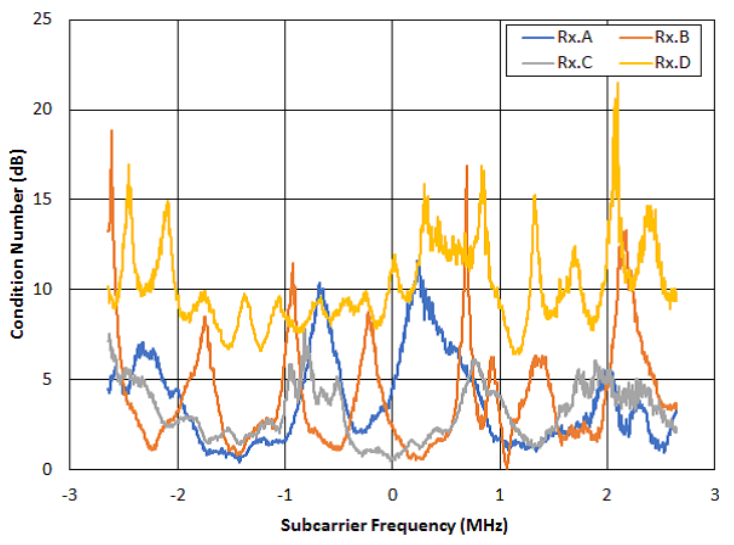

図 7 各受信点のサブキャリア毎の条件数

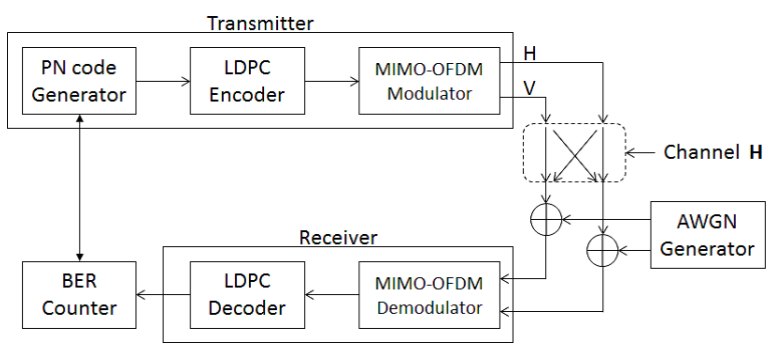

図 8 計算機シミュレーションのブロック図

リオデジャネイロは起伏の大きい地形を有する大都市で，高 層ビルが多数乱立している．本稿で使用する MIMO チャ ネルは，いずれも強電界地域のため現行 ISDB-T で受信実 態があるが，高層ビルの谷間などの見通し外環境やマルチ パス環境など受信状態の悪い地点において取得したもので ある４つの受信点（A,B,C,D）における MIMO チャネ ルを図 3〜6 に示す．受信点 $A, B, C$ はサブキャリアによっ て大きな電力差が生じており, 地上放送で受信特性が劣化 する典型的な伝搬環境（希望波電力とマルチパス電力の差 が小さい低 DUR(Desire to Undesire Ratio) マルチパス環 境）である。一方，受信点 $\mathrm{D}$ は高層ビルの谷間で測定され た MIMO チャネル応答で，主偏波成分 $\left(h_{00}, h_{11}\right)$ に比べ 交差偏波成分 $\left(h_{01}, h_{10}\right)$ の電力が大きく，帯域内で全体的 に交差偏波識別度が低い受信環境であることが分かる。リ オデジャネイロの野外実験で最も受信特性が劣化した伝搬 環境であった。本稿では，伝搬特性を式 (17) の条件数で評 価し，上記 4 つの受信点における各サブキャリア周波数の 条件数を図 7 に示す. 受信点 $\mathrm{D}$ は, 他の受信点に比べ条件 数が全体的に高く, より劣悪な伝搬条件（ill-condition）で ある．また，受信点 B は一部のサブキャリアの条件数が著 しく高い伝搬環境である.

\section{2 計算機シミュレーションの手法及び諸元}

計算機シミュレーションのブロック図を図 8 に示す。絶対 同期検波とし, 周波数オフセットの無い理想的な条件を仮定 する．評価パラメータである受信システム全体の搬送波電力 対雑音電力比 (CNR; Carreir to Noise Ratio) $\gamma$ は, $l$ 番目受 信アンテナ素子の受信電力, $\mathrm{CNR}$ をそれぞれ $P_{l}, \gamma_{l}=P_{l} / \sigma^{2}$ 


\begin{tabular}{c|c} 
表 1 計算機シミュレーションの伝送パラメータ \\
\hline \hline FFT size & 32768 \\
アクティブ・サブキャリア数 & 22465 \\
GI 比 (GI 長) & $1 / 32(126 \mu \mathrm{s})$ \\
キャリア変調方式 & $64 \mathrm{QAM}(M=6)$ \\
LDPC 符号長 & 64800 \\
LDPC 符号化率 & $3 / 4$ \\
復号アルゴリズム & Sum-Product 復号法 \\
繰り返し復号回数 & 50 \\
観測ビット数 & $10^{8}$ \\
LLR クリップ值 & 12.2 \\
\hline \hline
\end{tabular}

として

$$
\gamma=\frac{P_{0}+P_{1}}{2 \sigma^{2}}=\frac{1}{2}\left(\gamma_{0}+\gamma_{1}\right)
$$

と定める. また，伝送パラメータを表 1 に示す．実際に野外 実験で測定した MIMO チャネルを用いるため, OFDM サ ブキャリア数などの基本パラメータは野外実験に合わせた. LDPC 符号復号後の BER(Bit Error Rate) $<1.0 \times 10^{-7}$ で $\mathrm{BCH}$ 符号によりエラーフリーを擬似的に達成できると 仮定し, $\mathrm{BER}=1.0 \times 10^{-7}$ となる $\mathrm{CNR}$ を所要 $\mathrm{CNR}$ と定 義する ${ }^{18)}$. 平均雑音電力 $\sigma^{2}$ の推定, すなわち受信信号の CNR 推定方法としては様々な手法が提案されており ${ }^{19)}$, 本 稿では DBPSK 変調された TMCC,AC を用いて

$$
\sigma^{2}=\frac{1}{N_{X}} \sum_{n \in S} \min _{\mathbf{x}_{n} \in S_{X}}\left(\left|\mathbf{y}-\mathbf{H}_{n} \mathbf{x}_{n}\right|^{2}\right)
$$

と推定する.ただし, $S, N_{X}, S_{X}=\{(g, 0),(-g, 0)\}$ はそ れぞれ，1OFDM シンボルあたりの TMCC 信号又は AC 信号のサブキャリア・インデックスの集合, $1 \mathrm{OFDM}$ シンボ ルあたりの TMCC 信号又は $\mathrm{AC}$ 信号のサブキャリア数, 並 びに送信信号の集合 $(g$ : ブースト比)である. また, データ の信号検出や式 (27) の雑音電力推定で用いる MIMO チャ ネル $\mathbf{H}$ は, SP 信号を用いて推定する. 具体的には周波数 軸上の SP 信号を逆変調し, IFFT を行い時間領域のイン パルス応答を求める。 その後, 遅延時間が GI 長を超える 成分は除去し, 即ち折り返し成分を除去して FFTにより 最終的に周波数応答を推定する.

\section{3 計算機シミュレーション結果}

（1） MIMO 信号検出アルゴリズムの特性比較

各受信点のチャネル応答を用いた MIMO 信号検出の平均 BER 特性を比較する. 図 9〜12 に, ZF, MMSE, MLD, QRM-MLD, 並びに提案手法の平均 BER 特性を示す. ま ず, MLD, QRM-MLD, 5.1 の提案手法はいずれも, LLR の 算出において 5.2 に示す演算量削減を行わず，式 (10),(16) に基づき LLR を計算する. なお, QRM-MLD の $s$ 及び 提案手法の $\kappa_{\max }$ は, 平均 $\mathrm{BER}<10^{-7}$ を満足する平均 CNR が, 最適信号検出である MLD に較べて $0.1 \mathrm{~dB}$ 以 下の劣化に収まるように設定する. 各受信点における $s_{n}$ の帯域内平均值 $\bar{s}$ と, 各サブキャリアで平均化した $\kappa_{\max }$ の値を表 2 に示す．また, QRM-MLD 及び提案手法に着 目し, 受信点毎の $s$ 並びに $s_{n}$ に対する MLD からの所要 CNR 劣化量を図 13 に示す.

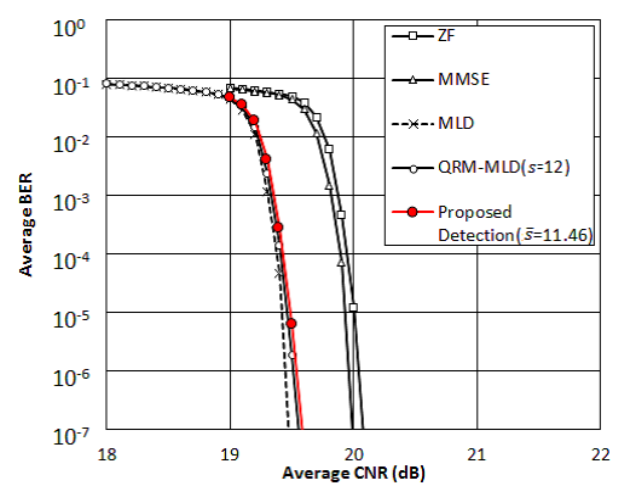

図 9 受信点 $\mathrm{A}$ の平均 BER 特性

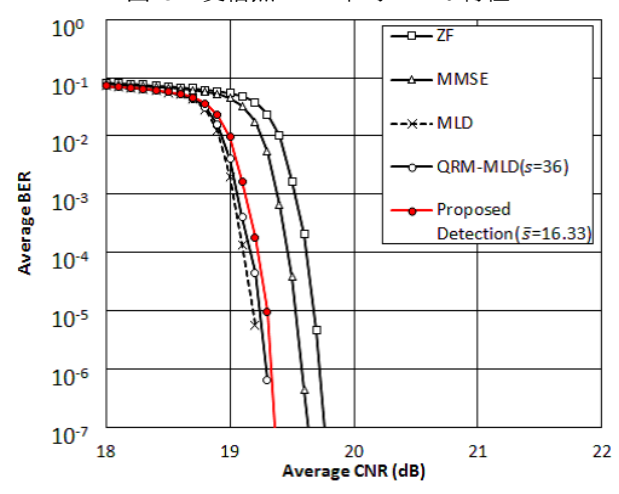

図 10 受信点 $\mathrm{B}$ の平均 BER 特性

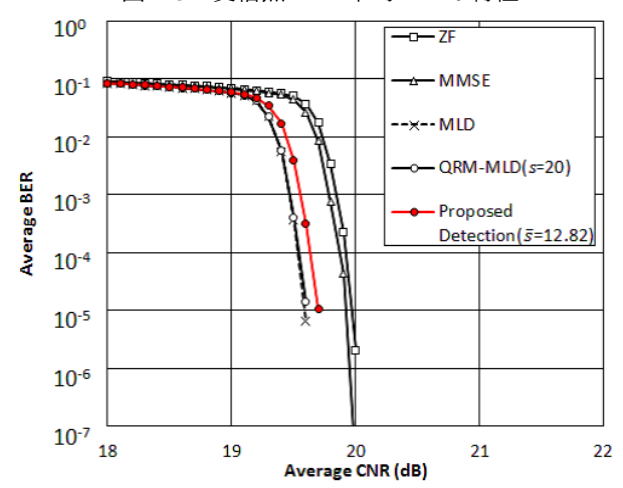

図 11 受信点 $\mathrm{C}$ の平均 BER 特性

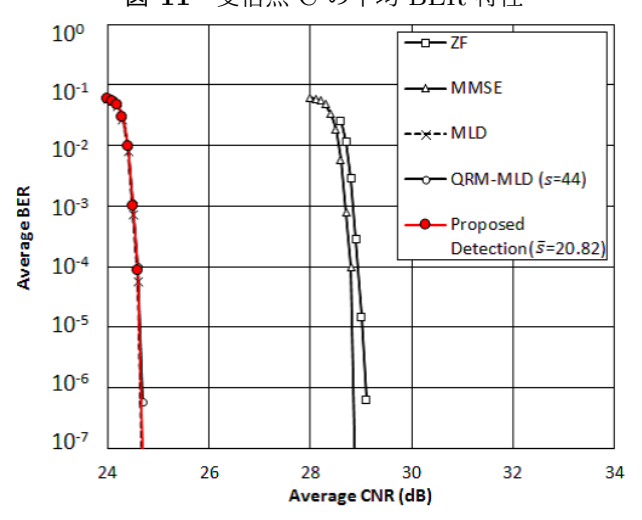

図 12 受信点 D の平均 BER 特性

図 9 12 から, MLD が一番平均 BER 特性が優れ, 次 いで QRM-MLD 及び提案手法, MMSE，ZF の順である ことが分かる.これらは一般的に知られている特性であり, 本稿で示した計算機シミュレーション結果の妥当性を裏付 けるものである. また, 受信点によっても優劣差にばらっ きがあり, 全体として伝搬環境が悪いほど所要 CNR が大 
表 2 信号候補数の带域内平均値 $\bar{s}$ と条件数の最大值 $\kappa_{\max }$

\begin{tabular}{c|c|c}
\hline 受信点 & $\bar{s}$ & $\kappa_{\max }(\mathrm{dB})$ \\
\hline $\mathrm{A}$ & 11.46 & 20.0 \\
$\mathrm{~B}$ & 16.33 & 17.5 \\
$\mathrm{C}$ & 12.82 & 25.0 \\
$\mathrm{D}$ & 20.82 & 30.0 \\
\hline \hline
\end{tabular}

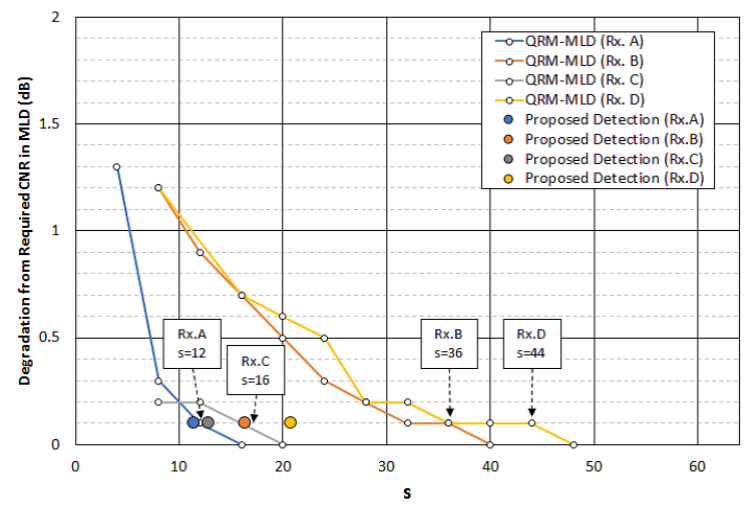

図 13 QRM-MLD の $s$ 対所要 CNR 劣化量と提案手法の比較

きくなり, MLD に対する劣化も大きくなることが分かる. 図 7 で明らかなように最も受信環境が悪い受信点 D では, 図 12 に示すように MLD と MMSE, ZF との所要 CNR 差 が $4 \mathrm{~dB}$ 以上あり, 帯域内の多くのサブキャリア周波数に おいて ill-condition となるためと考えられる.

従来の QRM-MLD と MLD の所要 CNR 差が $0.1 \mathrm{~dB}$ 以内となる $s$ 值は, 図 13 より受信点 A,B,C,D でそれぞ れ 12,36,16,44であった。受信点 D では伝搬環境が悪く, 条件数の帯域内平均值が高くなり, $s$ も高くなる傾向にあ る. 受信点 $\mathrm{B}$ は, 帯域内平均值は小さいものの最大值が大 きく，特定のサブキャリアにおける著しい劣化により $s$ が 大きくなっている. 受信点 B,D では, 提案手法によって, 所要 CNR の劣化を抑えつつ $s$ の帯域内平均值 $\bar{s}$ が従来の QRM-MLD に比べ小さくなっている. 一方, 受信点 $\mathrm{A}, \mathrm{C}$ では，図 7 で明らかなように受信点 $\mathrm{B}, \mathrm{D}$ に比べ全体的に条 件数が低く，ほとんどのサブキャリアで $10 \mathrm{~dB}$ 以下である ことが分かる．このような場合，元々の $s$ も大きくならな いため，提案手法を用いても， $s$ と $\bar{s}$ との差はわずかにな ると考えられる。

（2）計算量削減手法の検証

提案手法に対して 5.2 に示す Complex SD により LLR の演算量を削減し, 前節と同様のシミュレーションを行った. その結果を図 14〜17 に示す。ただし，信号候補数 $X$ は， $X=1,2,4,6$ とした. なお $X=1$ で, MAXLogMAP と 等価となる.いずれの受信点も, 想定した候補点を全て用い る $\operatorname{LogMAP}$ の平均 BER 特性が良く, 次いで $X=6,4,2,1$ の順に平均 BER 特性が良いことが分かる，Xの值が小さ いほど計算量を抑えることができ， $X=4$ で LogMAP か らの所要 $\mathrm{CNR}$ の劣化は $0.1 \mathrm{~dB}$ 以内に抑えられる. 提案 手法と提案手法+Complex SD の所要 CNR 差は, いずれ も $0.05 \sim 0.1 \mathrm{~dB}$ 程度に抑えられていることが分かる.さ

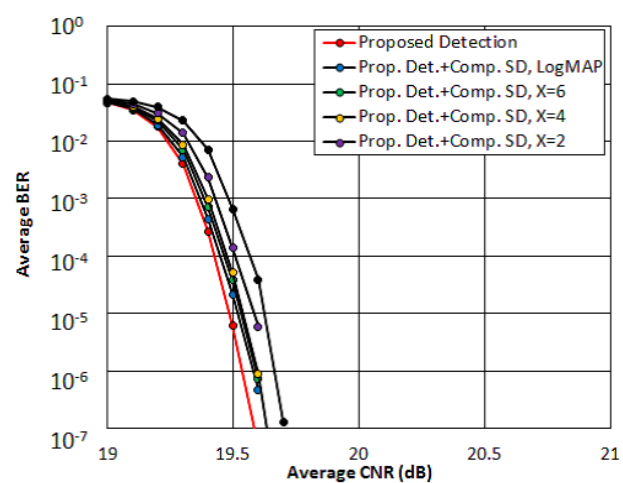

図 14 受信点 $\mathrm{A}$ の平均 $\mathrm{BER}$ 特性

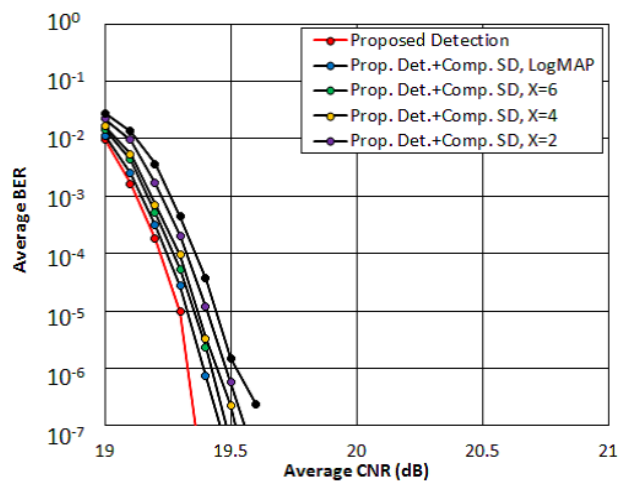

図 15 受信点 B の平均 BER 特性

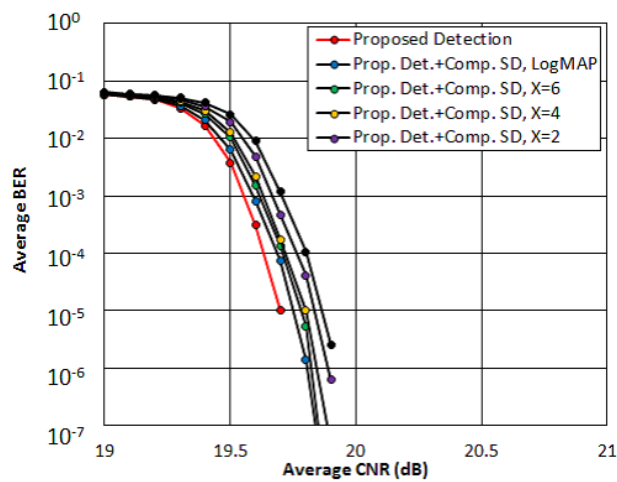

図 16 受信点 $\mathrm{C}$ の平均 $\mathrm{BER}$ 特性

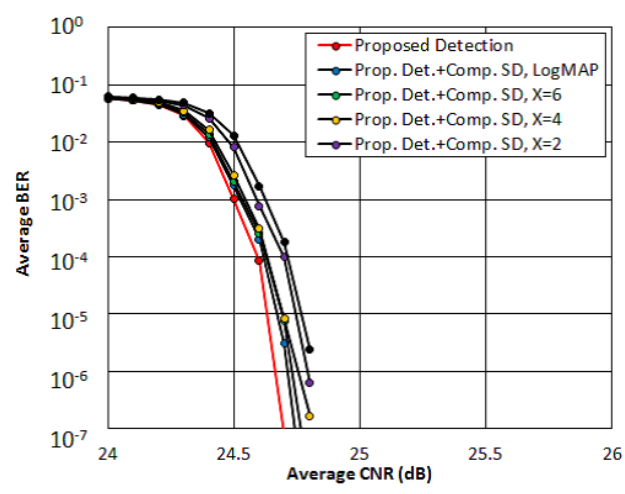

図 17 受信点 D の平均 BER 特性

らに，各受信点において式 (24)，(25) を適用した場合とし ない場合の BER 特性を図 18〜21 に示す。図 18〜21 に示 すシミュレーション結果は，いずれの受信点でも BER 特 性に $0.1 \mathrm{~dB}$ 以上の有意な差は見られないことから，本稿で 扱う MIMO チャネルにおいて式 (24), (25) に示す手法の 有効性を確認した。また，各受信点において LLR が $\pm \lambda_{c}$ 


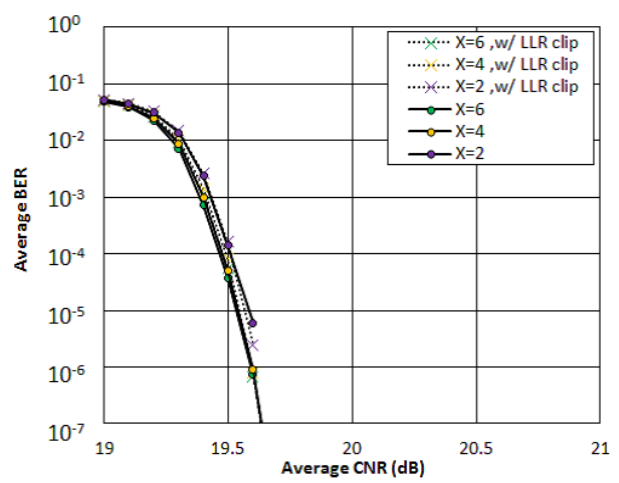

図 18 受信点 $\mathrm{A}$ における LLR クリップの特性比較

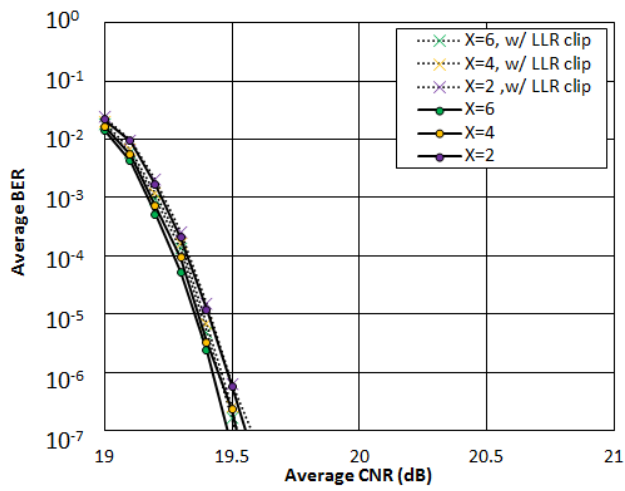

図 19 受信点 B における LLR クリップの特性比較

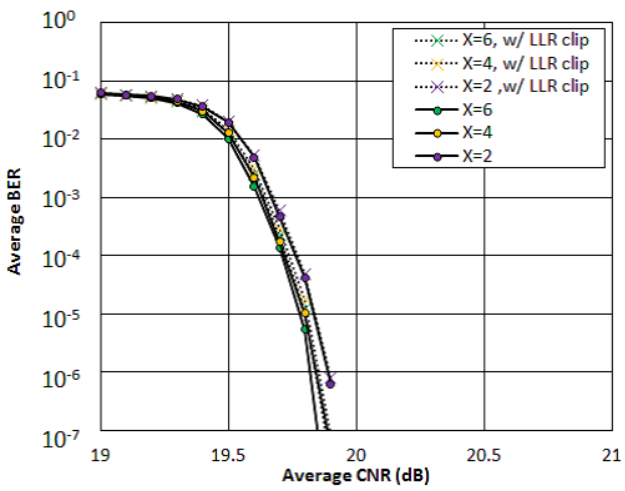

図 20 受信点 C における LLR クリップの特性比較

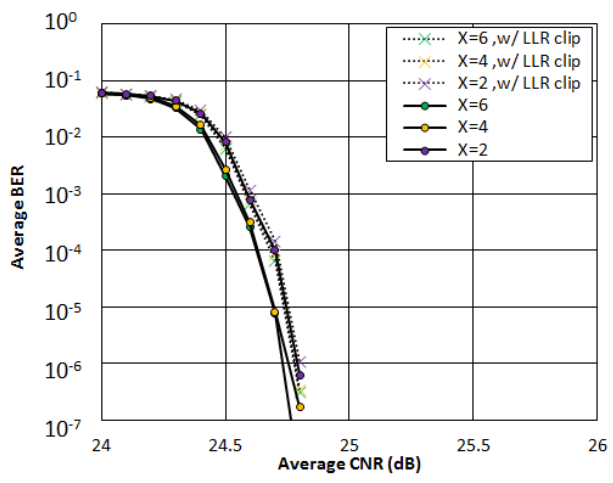

図 21 受信点 D における LLR クリップの特性比較

となる割合を調べた。伝送シミュレーション中の LLR が $\pm \lambda_{c}$ となる割合は厳密に一定ではないため, CNR を所要 CNR に固定して，伝送された符号の相加平均を取った．結 果を表 3 に示す．受信点によって割合は異なるが，1符号 中およそ 40〜 47\%のビットにおいて, LLR は式 (25)によ り計算を省略可能であることが分かる.

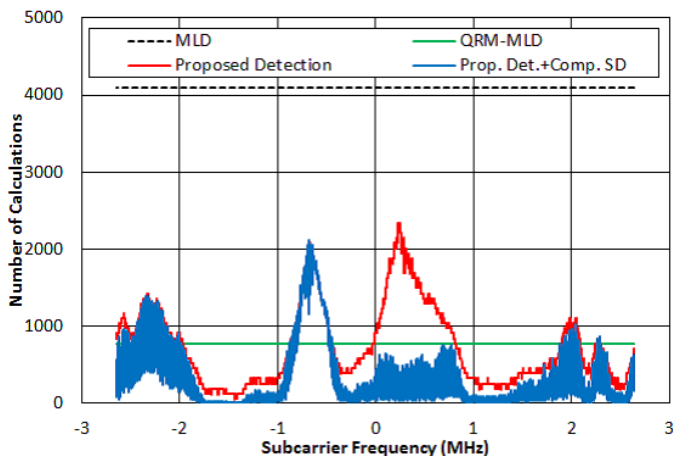

図 22 受信点 A における演算回数比較

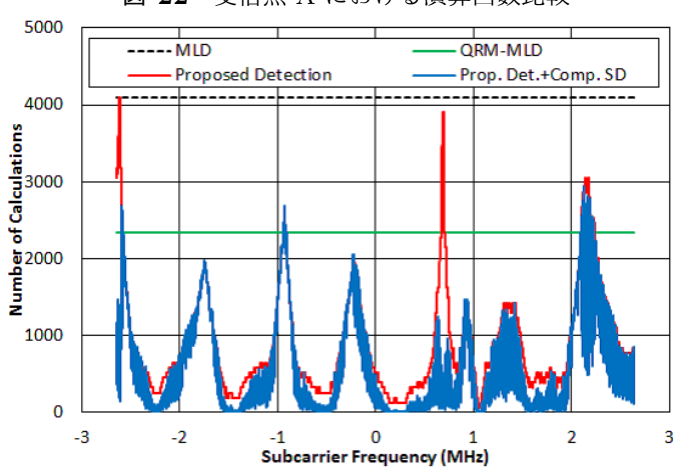

図 23 受信点 $\mathrm{B}$ における演算回数比較

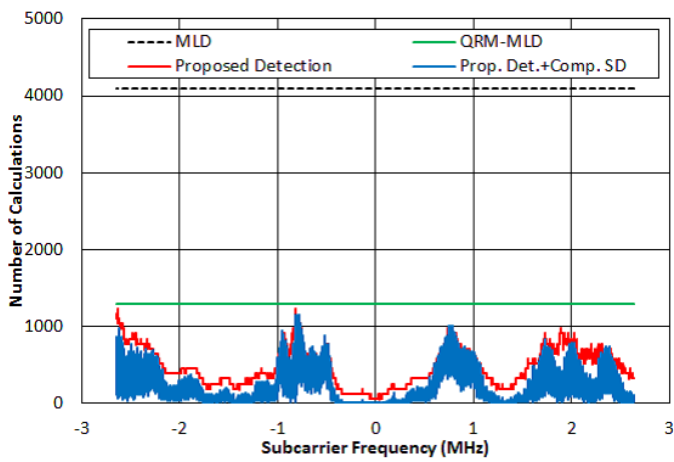

図 24 受信点 $\mathrm{C}$ における演算回数比較

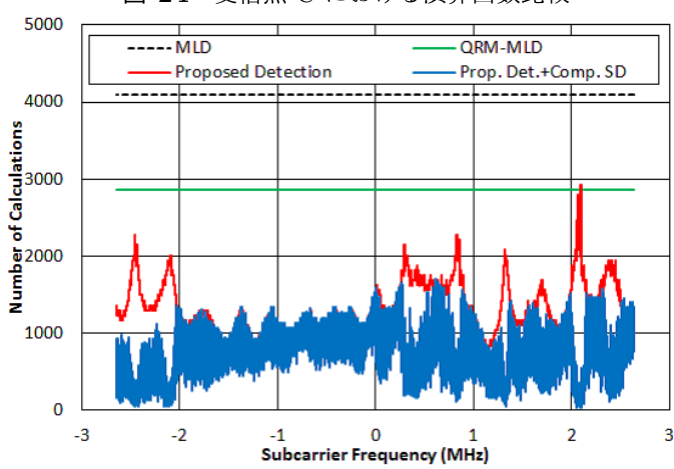

図 25 受信点 $\mathrm{D}$ における演算回数比較

次に，これらの手法によって削減される計算量について， 送信信号候補の 2 乗誤差の計算回数を評価パラメータとして 考察する. 4.4 で述べたとおり, MLD では $2^{2 M}$ 回, QRMMLD では第一段階で $s$ 回, 第二段階では第一段階の 1 候補 点に対して $2^{M}$ 回, 合計 $s 2^{M}$ 回の計算が必要である. MLD, QRM-MLD ( $s$ 一定 $)$, 提案手法, 提案手法 + Complex SD $(X=4)$ での各サブキャリアにおける計算回数を図 22〜 25 に示す.いずれの受信点も，提案手法+Complex SDに 


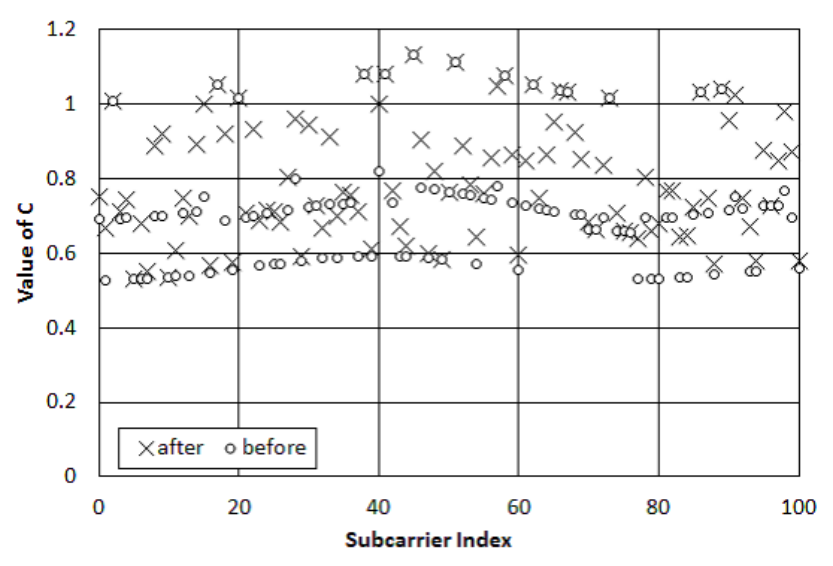

図 26 半径 $C$ の初期值, 設定値

表 $3\left|\lambda_{c}\right|$ の含まれる割合

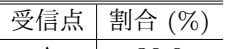

A 39.9

B 42.2

C $\quad 44.6$

$\mathrm{D} \quad 47.5$

表 4 二乗誤差計算回数の帯域内平均

\begin{tabular}{c|c|c|c|c}
\hline \hline 受信点 & MLD & $\begin{array}{c}\text { QRM-MLD } \\
(s \text { 一定 })\end{array}$ & 提案手法 & $\begin{array}{c}\text { 提案手法 } \\
\text { +Complex SD }\end{array}$ \\
\hline $\mathrm{A}$ & 4096 & 780 & 745.41 & 314.88 \\
$\mathrm{~B}$ & 4096 & 2340 & 904.27 & 560.46 \\
$\mathrm{C}$ & 4096 & 1300 & 486.99 & 214.07 \\
$\mathrm{D}$ & 4096 & 2860 & 1353.86 & 687.87 \\
\hline
\end{tabular}

表 5 半径の設定誤差

\begin{tabular}{c|c}
\hline \hline 受信点 & $E\left[C-C_{0}\right]$ \\
\hline $\mathrm{A}$ & 0.026 \\
$\mathrm{~B}$ & 0.036 \\
$\mathrm{C}$ & 0.014 \\
$\mathrm{D}$ & 0.065 \\
\hline \hline
\end{tabular}

よって，大幅に計算回数を削減できることが分かる．この場 合の, 各受信点における計算回数の帯域内平均值を表 4 に 示す. 所要 CNR が $0.05 \sim 0.1 \mathrm{~dB}$ のわずかな劣化で抑えら れているのに対し, 提案の MIMO 検出法 + Complex SD に よって, MLDに比べて約 83〜95\%の削減, QRM-MLD $(s$ 一定)に比べて約 60〜 84\%の削減ができる. また, 提案手 法と提案手法+Complex SD とを比較し, Complex SD に よって約 38〜 $58 \%$ の削減が可能であることが分かる.

5.2 で示した Complex SD 半径 $C$ の設定について考察 する. 一例として, 受信点 $\mathrm{D}$, サブキャリア番号 0 ～100 の 初期値 $C_{0}$ (before), 円内に $s$ 個が入るよう調整後の設定值 $C$ (after) の比較を図 $\mathbf{2 6}$ に示す. 初期值に比べ設定值がわ ずかに大きいものの，大きく外れるサブキャリアはなく効 率よく候補点探索が可能である. 初期值 $C_{0}$ と設定值 $C$ の 差分の帯域内平均値 $E\left[C-C_{0}\right]$ を表 $\mathbf{5}$ に示す. 本稿で用 いた受信点では, 0.07 未満の誤差で半径 $C$ の初期設定が可 能であった。

\section{7.むすび}

本論文では，次世代地上放送でも現行と同等もしくはそ
れ以上の受信性能が求められるため, 実測の劣悪な伝搬環 境を想定し，偏波 MIMO 伝送の信号検出アルゴリズムを 検討した。具体的には, LDPC 符号器へ入力するビット対 数尤度比を求める際, チャネル行列の $\mathrm{QR}$ 分解に基づき, 信号候補数をチャネル行列の条件数に応じて削減した。さ らに計算量を削減するため, Complex SD を導入し，LLR の数值範囲が限られているために, LLR をクリッピングす る方法を検討した。

提案の MIMO 信号検出が受信特性の劣化を抑えつつ信 号検出の演算量を効果的に削減できることを明らかにする ため, 計算機シミュレーションを行った。伝送路には, ブラ ジル・リオデジャネイロで行った野外実験によって測定し た，見通し外環境のチャネル応答を用いた。 まず，受信点毎 に平均 BER 特性を評価した。最適信号検出である MLD を基準にして，平均 $\mathrm{BER}=1.0 \times 10^{-7}$ を満たす $\mathrm{CNR}$ （所 要 CNR）の劣化が $0.1 \mathrm{~dB}$ 以下になるようパラメータを設 定した。劣悪な伝搬条件の 4 つの受信点において, 送信信 号候補の 2 乗誤差の計算回数を求め, 提案手法が MLD に 比べ最大 $95 \%$, 従来の QRM-MLD に対し最大 $84 \%$ の削減 が可能であることを示した。 また, Complex SD を導入し LLR の演算量削減効果を評価した。まず Complex SD の 半径設定手法を検討し，各受信点において 0.07 未満の誤差 で初期設定が可能であることを明らかにした．次に計算機 シミュレーションの結果, 受信信号近傍の送信信号候補を 4 個未満に限定することで，候補点削減後に残存した送信信 号候補を全て用いる手法に比べ，所要 CNR 劣化が $0.1 \mathrm{~dB}$ 以内を保ちつつ演算量をさらに最大 $58 \%$ の削減が可能であ ることを明らかにした。ささらに，1 LDPC 符号に含まれる LLR の内，およそ 40〜 47\%のビットにおいて，LLR はク リッピングにより演算を省略可能であることを示した。

今後の課題として, 偏波 MIMO 伝送の移動受信特性の検 討が挙げられる．現行 ISDB-T の重要な特徵として，固定 受信向けサービス (フルセグ) と移動体向けサービス (ワン セグ）を周波数分割多重 (FDM; Frequency Division Multiplexing）によって1 チャンネル内で同時に提供可能であ ることが挙げられる，そのため，次世代地上放送において も，ISDB-T の特徵を踏襲し移動体向けサービスを検討す る必要がある。一般的に固定受信に比べ，移動受信は受信 環境が悪いため，本稿で検討した受信アルゴリズムの適用 が期待できる．ただし，移動受信環境は固定受信と異なり， チャネル応答が時間変動するため，チャネルの状態を効率 よく推定することが課題となる.

\section{〔文献〕}

1) M.Taguchi, K. Murayama, T. Shitomi, S. Asakura, K. Shibuya: "Large-Capacity Wireless Transmission Technology", ITA Trans. on MTA, 1, 1, pp.34-39 (Jan. 2013)

2) ITU-R BT.2343-2 : "Collection of Field Trials of UHDTV over DTT networks" (2016)

3）電波産業会: “地上デジタル放送の伝送方式”, ARIB STD-B31 v2.2 (2014)

4) S.Asakura, H.Miyasaka, M. Nakamura, K.Murayama, K. 
Tsuchida, C. Rodrigues, and G. Ferraresso: "Performance of Dual-Polarized MIMO-High-Order-Modulation OFDM in Deteriorated Transmission Channel", IEEE International Symposium on BMSB , mm17-041(Jun. 2017)

5）大鐘武雄, 小川恭孝：“わかりやすい MIMO システム技術”，オーム社 (2009)

6）樋口, 川合, 前田, 佐和橋 : “QRM-MLD を用いる OFCDM MIMO 多 重における信頼度情報を用いる適応生き残りシンボルレプリカ候補選択 法”, 信学技報, RCS2004-69 (Jul. 2004)

7) H. Shen, H. Zhang, and C. Zhao: "An Efficient Adaptive Receiver for MIMO-OFDM Systems", Int. Conf. on Wireless Communications and Signal Processing(WCSP) (Dec. 2011)

8) H. Kawai, K. Higuchi, N. Maeda, and M. Sawahashi: "Independent adaptive control of surviving symbol replica candivates at each stage based on minimum branch metric in QRM-MLD for OFCDM MIMO multiplexing", IEEE 60th VTC-Fall, pp.15581564 (2004)

9) D. L. Milliner, E. Zimmermann, J. R. Barry, and G. Fettweis: "Channel state information based LLR clipping in list MIMO detection", IEEE 19th International Symposium on PIMRC (2008)

10) Europian Standard: "Digital Video Broadcasting(DVB); Framing structure, channel coding, and modulation for digital terrestrial television", ETSI EN 300744 V1.6.2 (2015)

11) J. D Mitchell, P.N. Moss, and M.J. Thorp: "A Dual Polarisation MIMO Broadcast TV System", BBC Research White Paper, WHP144 (2006)

12) P. Moss, T.Y. Poon, and J. Boyer: "A Simple Model of the UHF Cross-Polar Terrestrial Channel for DVB-NGH", BBC Research White Paper, WHP205 (2011)

13) ATSC standerd: "Physical Layer Protocol", A/322 (2017)

14) D.G. Barquero, D. Vagas, M. Fuentes, P. Klenner, S. Moon, J.Y. Choi, D. Schneider, and K. Murayama: "MIMO for ATSC3.0", IEEE Trans. on Broadcasting, 62, 1, pp.298-305 (Mar. 2016)

15) T. Shitomi, E. Garro, K. Murayama, and D.G. Barquero : "MIMO Scattered Pilot Performance and Optimization for ATSC3.0", IEEE Trans. on Broadcasting, 64, 2, pp.188-200 (Dec. 2017)

16）朝倉, 蔀, 田口, 村山, 土田, 涉谷: “偏波 MIMO 伝送におけるインター リーブ手法の検討”, 映情义学誌, 69, 12, pp.320-327 (Dec. 2015)

17) B.M. Hochwald and S.T. Brink: "Achieving Near-Capacity on a Multiple-Antenna Channel", IEEE Trans. on Communications, 51, 3, pp.389-399 (Apr. 2003)

18) ITU-R BT.2389-0 : "Guidelines on Measurements for Digital Terrestrial Television Broadcasting Systems" (2016)

19) G. Ren, H. Zhang, and Y. Chang: "SNR Estimation Algorithm Based on the Preamble for OFDM Systems in Frequency Selective Channels", IEEE Trans. on Communications, 57, 8, pp.2230-2234 (Aug. 2009)

20）和田山正：“低密度パリティ検査符号とその復号法”, トリケップス社 (2002)

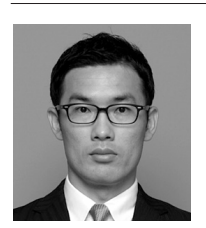

朝倉 慎悟 2006 年, 東京工業大学大学院総合理 工学研究科修了. 同年, NHK 入局. 岡山放送局を経て, 2010 年より放送技術研究所に所属. 次世代地上放送方 式の研究・開発に従事. 正会員.

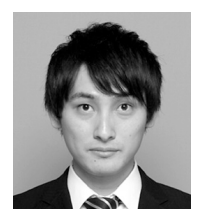

宮坂 宏明 2009 年, 東京理科大学大学院基礎工学 研究科修了. 同年, NHK 入局. 釧路放送局を経て, 2013 年より放送技術研究所に所属. 次世代地上放送方式の研 究・開発に従事. 正会員.

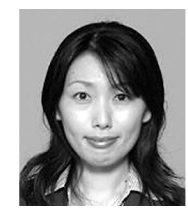

なかむら字どか 200 年，東京工業大学大学院理工学 研究科修了。同年, NHK 入局. 仙台放送局, 技術局を 経て, 2006 年から放送技術研究所にて, 大容量光伝送技 術, 次世代地上伝送技術の研究に従事. 現在, 伝送シス テム研究部上級研究員. 正会員.

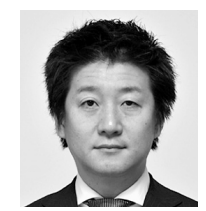

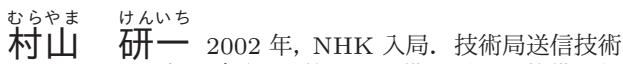
センターにて地上デジタル放送用設備の開発・整備に従 事. 2008 年より，放送技術研究所にて次世代地上放送 方式の研究に従事. 現在，技術局計画管理部副部長. 正 会員.

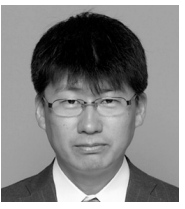

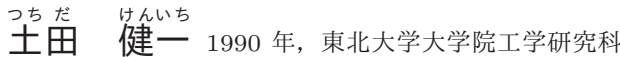
（情報工学専攻）修了. 同年, NHK 入局. 静岡放送局, 放送技術研究所，技術局を経て，2011 年より放送技術 研究所に所属. 次世代地上放送方式の研究・開発に従事. 現在，伝送システム研究部上級研究員. 正会員.

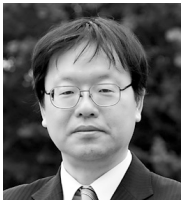

府加架和篇 1985 年, 東京工業大学理学部卒. 1987 年, 同大学理工学研究科. 物理学専攻修士了. 同年, 日 本電信電話株式会社入社, 1992 年, NTT 移動通信網株 式会社へ転籍, 1998 年, 東京工業大学.工学博士, 2000 年, 東京工業大学. 助教授, 2014 年, 同大学大学院理工 学研究科. 教授, 現在に至る. 1987 年以来, ディジタル 移動通信の伝送技術及びネットワーク技術の研究に従事. 